\title{
Association of genetic variants in chromosome 17q21 and adult-onset asthma in a Chinese Han population
}

\author{
Rongfang Qiu', Hailing Zhao', Aihua Wang ${ }^{2}$, Yaogin Gong ${ }^{1}$ and Qiji Liư ${ }^{*}$
}

\begin{abstract}
Background: Genome-wide association studies of asthma have identified a novel region containing ORMDL3 at chromosome 17q21 that is strongly associated with childhood-onset asthma and significantly linked to ORMDL3 transcript abundance. These results have been successfully replicated in childhood-onset asthma cohorts in several ethnic groups. In this study, we aimed to evaluate the association of polymorphisms in ORMDL3, GSDMB, ZPBP2 and IKZF3 and adult-onset asthma in a Chinese Han population.

Methods: We genotyped 5 single nucleotide polymorphisms (SNPs) at chromosome 17q21 in 1,366 Han Chinese people comprising 710 patients with adult-onset asthma and 656 healthy controls. We compared the 2 groups in terms of allele and haplotype frequencies. Transcript levels were measured in leukocytes from 61 asthma patients by quantitative real-time PCR.

Results: We found the 5 SNPs significantly associated with asthma ( $P<0.05)$, of which 2, rs 11557467 and rs9303277, were strongly associated $(P<0.001)$. Subjects carrying the $G$ allele of rs 11557467 or the $C$ allele of rs9303277 showed increased risk of asthma (odds ratio [OR] 1.27, 95\% confidence interval 1.07-1.51, $\mathrm{P}=0.006$, and OR 1.27, 1.07-1.49, $P=0.005$, respectively), even after adjusting for age and sex. The risk of asthma was lower for carriers of the haplotype CTGTT (OR 0.81, 0.67-0.97, P = 0.02). The risk allele for each SNP was associated with increased expression of ORMDL3 and GSDMB in leukocytes (all $p<0.05$ ).
\end{abstract}

Conclusions: Our replication study suggests that variants in 17q21 are significantly associated with risk of adultonset asthma and gene expression in a Chinese Han population.

\section{Background}

Asthma is a complex disease triggered by the interaction of genetic predisposition and environmental factors [1,2]. Recently, the first genome-wide association study (GWAS) of asthma in European subjects identified a novel region containing the ORM1-like 3 (ORMDL3) gene at chromosome $17 \mathrm{q} 21$ strongly associated with childhood asthma and $O R M D L 3$ transcript abundance [3].

ORMDL3, located at $17 \mathrm{q} 21.1$, belongs to a novel gene family that also includes ORMDL1 and ORMDL2[4]. Breslow et al. recently found Orm proteins as mediators of sphingolipid homeostasis and suggested that sphingolipid

\footnotetext{
* Correspondence: liuqiji@sdu.edu.cn

'Key Laboratory for Experimental Teratology of the Ministry of Education and Department of Medical Genetics, Shandong University School of Medicine, Jinan, Shandong 250012, PR China

Full list of author information is available at the end of the article
}

misregulation might be related to the development of childhood asthma [5]. GSDMB, encoding the protein gasdermin $\mathrm{B}$, a member of the cancer-associated gasdermin-domaincontaining protein family implicated in cancer pathogenesis [6], is adjacent to ORMDL3 on chromosome 17.

$O R M D L 3$ as a candidate gene for asthma susceptibility has been replicated in 8 white populations (Scottish [7], French-Canadian [8,9], French [8], German and British ancestry [3], North Americans of European ancestry [10], Mexicans in Mexico City [11] and Australia [12]), 3 ethnically diverse populations (Mexicans, Puerto Ricans and African Americans) [13], and 2 Asian populations (Japanese [14] and Chinese [Hong Kong][15]). However, all these associations were for childhood asthma.

To validate whether ORMDL3 is a risk factor for adult-onset asthma, we sought to replicate the association of polymorphisms in ORMDL3, GSDMB, ZPBP2

\section{() Biomed Central}

(c) 2011 Qiu et al; licensee BioMed Central Ltd. This is an Open Access article distributed under the terms of the Creative Commons Attribution License (http://creativecommons.org/licenses/by/2.0), which permits unrestricted use, distribution, and reproduction in any medium, provided the original work is properly cited. 
Table 1 Clinical and demographic characteristics of patients and controls

\begin{tabular}{lll}
\hline Characteristics & Patients & Controls \\
\hline No. of subjects & 710 & 656 \\
Age, mean (range), years & 28.7 & 29.1 \\
& $(22-37)$ & $(20-42)$ \\
Sex (male/female) & $345 / 365$ & $310 / 346$ \\
FVC (\% predicted), mean \pm SD & $67.7 \pm 17.2$ & $80.6 \pm 15.4$ \\
FEV1 (\% predicted), mean \pm SD & $56.4 \pm 16.8$ & $87.9 \pm 12.2$ \\
$\%$ change in FEV1 by bronchodilator, mean $\pm S D$ & $28.2 \pm 14.6$ & $4.3 \pm 3.9$ \\
\hline
\end{tabular}

FVC: forced vital capacity; $\mathrm{FEV}_{1}$ : forced expiratory volume in $1 \mathrm{~s}$.

and IKZF3 and asthma in an adult Chinese Han population. We also determined whether these variants are associated with gene levels in leukocytes.

\section{Methods}

\section{Subjects}

We included 1,366 unrelated subjects of exclusively Han ethnicity in this case-control study. From 2008 to 2009, we recruited 710 adult-onset asthma patients from Qilu Hospital, Jinan. All patients met the 1987 criteria for asthma of the American Thoracic Society (ATS, 1987). We also recruited 656 unrelated, random-sampled healthy controls who were matched to cases by age, ethnicity and geographic region, who underwent comprehensive medical screening at Qilu Hospital and were without symptoms or history of asthma or other pulmonary diseases or atopy. Healthy controls had no firstdegree relatives with asthma nor history of asthma or atopy at the time of recruitment [16].

The mean age of asthma onset in patients was 25 years. Onset age was confirmed by physicians asking the question "How old were you when you first experienced the asthma symptoms of wheezing, shortness of breath, chest tightness and coughing?" Patients with vague answers to the question were not included. We included only patients with asthma onset at age 18 years or older. Clinical and demographic characteristics of patients and controls are in Table 1.

Blood samples were obtained from all participants after their informed consent. Genomic DNA was extracted from peripheral blood leukocytes by a standard phenol-chloroform method. Total RNA was extracted from leukocytes by the TRIZOL reagent method (Invitrogen, Carlsbad, CA). For transcript analysis, we selected samples for 61 patients who were first-episode asthma patients and had not received any medication within the previous month.

The study was approved by the ethics review committee for human studies at the School of Medicine, Shandong University.

\section{Single nucleotide polymorphism selection and genotyping}

We selected 5 single nucleotide polymorphisms (SNPs) according to previous results and the linkage disequilibrium (LD) status in HCB. rs7216389, rs12603332 and rs12936231 were genotyped by PCR-restriction fragment-length polymorphism analysis. PCR amplification conditions were optimized with an initial denaturation step at $95^{\circ} \mathrm{C}$ for $5 \mathrm{~min}$, then 35 cycles of denaturation at $94^{\circ} \mathrm{C}$ for $40 \mathrm{~s}$, annealing at optimal temperature for $40 \mathrm{~s}$ and extension at $72^{\circ} \mathrm{C}$ for $50 \mathrm{~s}$, and a final extension at $72^{\circ} \mathrm{C}$ for $10 \mathrm{~min}$ in a thermal cycler. Then, PCR products were digested with locus-specific restriction endonucleases (New England BioLabs, Beijing) and were electrophoresed on agarose gels. rs9303277 and rs11557467 were genotyped by the TaqMan SNP genotyping method with assay-on-demand probes and primers (C_9272050_20 for rs9303277, C_9272244_10 for rs11557467, Applied Biosystems, Foster City, USA). Genotyping accuracy was confirmed by direct sequencing of PCR products for $5 \%$ randomly chosen samples. Primers and restriction endonucleases are in Table 2.

\section{Gene splicing}

The SNPs located in the intron may affect mRNA splicing. According to the ensemble database, ORMDL3 contains 2 transcripts: ENST00000304046 (ORMDL3-001) and ENST00000394169 (ORMDL3-002). To assess whether rs12603332, located in the first intron, might affect gene splicing, we designed 2 pairs of primers. One pair, located in the first and second exons, would amplify both

Table 2 Primers used in PCR-restriction fragment-length polymorphism (RFLP) and gene splicing analysis

\begin{tabular}{|c|c|c|c|c|c|}
\hline SNP & alleles & PCR primer & PCR product & Restriction enzyme & RFLP products (bp) \\
\hline rs7216389 & $T / G$ & $\begin{array}{l}\text { F:5'-GTCACATTTCCACCAGTT-3' } \\
\text { R:5'-CTGTAATCCCAGCACTT-3' }\end{array}$ & $563 \mathrm{bp}$ & Nsi I & $334 / 229$ \\
\hline rs12603332 & $\mathrm{A} / \mathrm{C}$ & $\begin{array}{c}\text { F:5'-GAGTGTCTGGCATACTGGCTGG-3' } \\
\text { R:5'CCGAAAACTTCTGCTGCCATAGCTGGCACG-3' }\end{array}$ & $214 \mathrm{bp}$ & BstU I & $174 / 30$ \\
\hline rs12936231 & $C / G$ & $\begin{array}{l}\text { F:5'-TATGACATATTGTTGCTTCT-3' } \\
\text { R:5'-ATAGACTCACAAAGGGATTC-3' }\end{array}$ & 349bp & Bsl I & 191/158 \\
\hline \multirow[t]{2}{*}{$\begin{array}{l}\text { rs12603332 } \\
\text { (gene splicing) }\end{array}$} & & $\begin{array}{l}\text { F1:5'-GACCCTCACCAACCTCATTCAC-3' } \\
\text { R1:5'-CCATAATCCATCTGCTCCCAGTG-3' }\end{array}$ & $129 \mathrm{bp}$ & & \\
\hline & & $\begin{array}{l}\text { F2:5'- AGGGAATGGGAAGGGCTCAC-3' } \\
\text { R2:5'- CGGCATGTGGCTGACAAGTG-3' }\end{array}$ & $801 \mathrm{bp}$ & & \\
\hline
\end{tabular}


transcripts. Another pair, located in the 3' untranslated region of the second transcript, would yield products only when the second transcript was present. We conducted this experiment in 10 samples, half of them containing the CC genotype and half the TT genotype in the rs12603332 site. Primer sequences are available upon request.

\section{Transcript level analysis}

To determine the impact of rs7216389, rs12603332, and rs12936231 SNPs on the gene expression of GSDMB and ORMDL3, we performed real-time PCR for different genotype groups using peripheral leukocyte RNA from 61 patients. We determined relative mRNA levels of human ORMDL3, and GSDMB, with human GAPDH mRNA used as an internal control, using an ABI 7500 real-time PCR system. The comparative threshold cycle method $\left(\mathrm{C}_{\mathrm{T}}\right)$ was used to quantitate mRNA. Four duplicate wells were used for each subject.

\section{Statistical analysis}

SNPs were tested for deviation from Hardy-Weinberg equilibrium by chi-square test. Categorical data were compared by Fisher's exact test and allelic expression level by one-way ANOVA. The allele and genotype frequencies, odds ratios (ORs) with $95 \%$ confidence intervals (95\% CIs), and $\mathrm{p}$ values were analyzed by use of PLINK 1.07[17]. Pairwise LD was measured by use of Haploview 4.2. Fivelocus haplotypes were estimated with a full-precise-iteration (FPI) algorithm by use of the online SHEsis software [18]. A p $<0.05$ was considered statistically significant.

\section{Results}

\section{Association study}

Genotype and allele frequencies for each SNP are in Table 3. The distributions of the 5 SNPs were in HardyWeinberg equilibrium $(\mathrm{P}>0.05)$ for both patients and controls. To test the association of each locus with

Table 3 Genotype and allele association analysis of 5 single nucleotide polymorphisms

\begin{tabular}{|c|c|c|c|c|c|c|c|}
\hline SNP ID & $\begin{array}{l}\text { Polymorphisms } \\
\text { Genotype/allele }\end{array}$ & $\begin{array}{l}\text { Patients with } \\
\text { asthma, n (\%) }\end{array}$ & Controls, n (\%) & OR & $95 \% \mathrm{Cl}$ & $P$ value & $\mathrm{P}^{*}$ \\
\hline \multirow{5}{*}{$\begin{array}{l}\text { rs7216389 } \\
\text { (GSDMB) }\end{array}$} & $\pi$ & $384(55.2)$ & $298(46.8)$ & 1 & & & \\
\hline & $\mathrm{CT}$ & $258(37.1)$ & $286(44.9)$ & 1.43 & $1.14-1.80$ & 0.008 & \\
\hline & $\mathrm{CC}$ & $54(7.7)$ & $53(8.3)$ & 1.27 & $0.84-1.90$ & & 0.01 \\
\hline & T & $1026(73.7)$ & $882(69.2)$ & 1 & & 0.011 & \\
\hline & C & $366(26.3)$ & $392(30.8)$ & 1.25 & $1.05-1.48$ & & \\
\hline \multirow{5}{*}{$\begin{array}{l}\text { rs12603332 } \\
\text { (ORMDL3) }\end{array}$} & CC & $385(54.2)$ & $302(46.04)$ & 1 & & & \\
\hline & $\mathrm{CT}$ & $268(37.8)$ & 300 (45.73) & 1.43 & $1.14-1.784$ & 0.007 & \\
\hline & $\pi$ & $57(8.0)$ & $54(8.23)$ & 1.21 & $0.81-1.81$ & & 0.01 \\
\hline & $C$ & $1038(73.1)$ & $904(68.9)$ & 1 & & 0.016 & \\
\hline & T & $382(26.9)$ & 408 (31.1) & 1.23 & $1.04-1.45$ & & \\
\hline \multirow{5}{*}{$\begin{array}{c}\text { rs12936231 } \\
\text { (ZPBP2) }\end{array}$} & CC & $393(56.1)$ & $298(47.8)$ & 1 & & & \\
\hline & $C G$ & $257(36.7)$ & $278(44.6)$ & 1.43 & $1.14-1.79$ & 0.009 & \\
\hline & GG & $50(7.1)$ & $47(7.5)$ & 1.24 & $0.81-1.90$ & & 0.01 \\
\hline & C & $1043(74.5)$ & $874(70.0)$ & 1 & & 0.013 & \\
\hline & G & $357(25.5)$ & $372(30.0)$ & 1.24 & $1.05-1.48$ & & \\
\hline \multirow{5}{*}{$\begin{array}{l}\text { rs11557467 } \\
\text { (ZPBP2) }\end{array}$} & GG & 383 (55.51) & $300(46.80)$ & 1 & & & \\
\hline & GT & $257(37.25)$ & $288(44.93)$ & 1.43 & $1.14-1.79$ & 0.006 & \\
\hline & $\pi$ & $50(7.25)$ & $53(8.27)$ & 1.35 & $0.89-2.05$ & & 0.005 \\
\hline & G & $1023(74.13)$ & $888(69.27)$ & 1 & & 0.006 & \\
\hline & $\mathrm{T}$ & $357(25.87)$ & 394 (30.73) & 1.27 & $1.07-1.51$ & & \\
\hline \multirow{5}{*}{$\begin{array}{l}\text { rs9303277 } \\
\text { (IKZF3) }\end{array}$} & CC & 348 (50.58) & $269(42.43)$ & 1 & & & \\
\hline & CT & $278(40.41)$ & $295(46.53)$ & 1.37 & $1.09-1.73$ & 0.012 & \\
\hline & $\pi$ & $62(9.01)$ & $70(11.04)$ & 1.46 & $1.00-2.13$ & & 0.004 \\
\hline & C & 974 (70.78) & 833 (65.69) & 1 & & 0.005 & \\
\hline & $\mathrm{T}$ & 402 (29.22) & 435 (34.31) & 1.27 & $1.07-1.49$ & & \\
\hline
\end{tabular}


asthma, we compared cases and controls in terms of allele frequency and genotype distribution for each polymorphism. All SNPs were significantly associated with asthma, even after adjusting for age and sex.

\section{Gene splicing}

PCR results were similar for both CC and TT homozygotes at rs12603332 (Figure 1). Only the first pair of primers yielded products for all cDNA samples. However, the second pair of primers yielded PCR products when genomic DNA was used as a template. Therefore, only the ORMDL3-001 transcript was expressed in all samples.

\section{Transcript level analysis}

The SNPs rs7216389, rs12603332, and rs12936231 had striking effects on ORMDL3 and GSDMB expression (Figure 2). The expression level was robustly increased in homozygotes for risk alleles as compared with those carrying 1 or 2 copies of the reference alleles.

\section{LD evaluation and haplotype analysis}

As expected, all 5 SNPs were in strong LD, with $r^{2}>$ 0.75 (Figure 3). This result is consistent with the data from Hapmap HCB. We identified 11 different haplotypes by haplotype analysis (Table 4). However, only 3 had a frequency $>1 \%$. The haplotype analysis results were the same as the single-site association results. As compared with the haplotype TCCCG, CTGTT was a risk factor, with OR $=0.81$ (95\% CI 0.67-0.97, p 0.021).

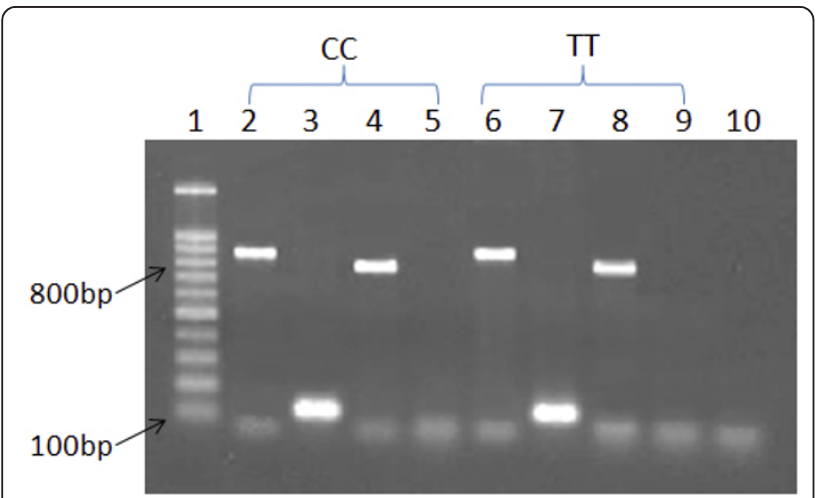

Figure 1 Absence of alternate exon splicing in ORMDL3 Subjects with the CC genotype are in lanes 2 to 5 and those with the $\Pi$ genotype are in lanes 6 to 9 . We used cDNA as a template in lanes 3, 5, 7, and 9 and genomic DNA as a template in lanes 2, 4, 6 , and 8 . The first pair of primers was used in lanes $2,3,6$, and 7 and the second pair of primers in lanes 4, 5, 8, and 9. However, only the first pair of primers worked in CDNA for subjects with both CC and $\Pi$ genotypes. Lanes 1 and 10 are the 100-bp markers and PCR negative control, respectively.

\section{Discussion}

Family and twin studies have implicated genetic components in the pathogenesis of asthma $[19,20]$. However, although several asthma susceptibility genes have been identified, the complex etiology, combined with extensive heterogeneity, has made genetic studies of asthma challenging. Recently, the first GWAS for asthma identified ORMDL3 as a new asthma candidate gene[3], and subsequent studies confirmed the association of polymorphisms in the chromosome region with asthma in different ethnic groups[3,7-11,13-15]. In 2010, Moffatt et al. confirmed ORMDL3 as an important asthma susceptibility gene in their consortium-based GWAS[21]. In this study, we confirmed the association of chromosome 17q21 SNPs and expression of asthma-associated genes with susceptibility to asthma in an adult Chinese Han population.

Our results are different from many previous studies finding an association of $17 \mathrm{q} 21$ variants and childhoodonset asthma. Our study is among the first to report the association of genetic variants in this locus and adultonset asthma. Not much is known about the differences between early- and adult-onset asthma in terms of disease mechanisms. We believe childhood- and adultonset asthma may share certain disease mechanisms. Exposure to strong or cumulative environmental triggers such as pollution or infection may be responsible for adult-onset cases. Such triggers may not have existed during the patients' childhood or might have been weaker, such as for patients living in regions under rapid transition from agricultural economy to industrialization. Our results, from a genetics viewpoint, supports the notion that similar mechanisms may exist in childhood- and adult-onset asthma.

Our study contains some limitations in that it may reflect recall bias in self-reported age of asthma onset. Also, the 5 SNPs studied were in complete LD, so we did not perform a multiple test correction to avoid increasing the II error.

Although GWASs have successfully identified common variants associated with a wide variety of complex diseases, the design cannot establish causality of diseaseassociated SNPs. For the variants at chromosome 17q21, which are in a large strongly LD region, disentangling which gene or SNP is the true functional locus that contributes independently to the asthma susceptibility is difficult.

Many groups have tried to identify causal variants. Recently, Verlaan et al. discovered a striking correlation between rs12936231 and ORMDL3, GSDMB and ZPBP2 gene expression, and this variant may be one of the causal SNPs because it alters the binding of insulator protein CTCF (CCTC binding protein)[22]. Gerard 


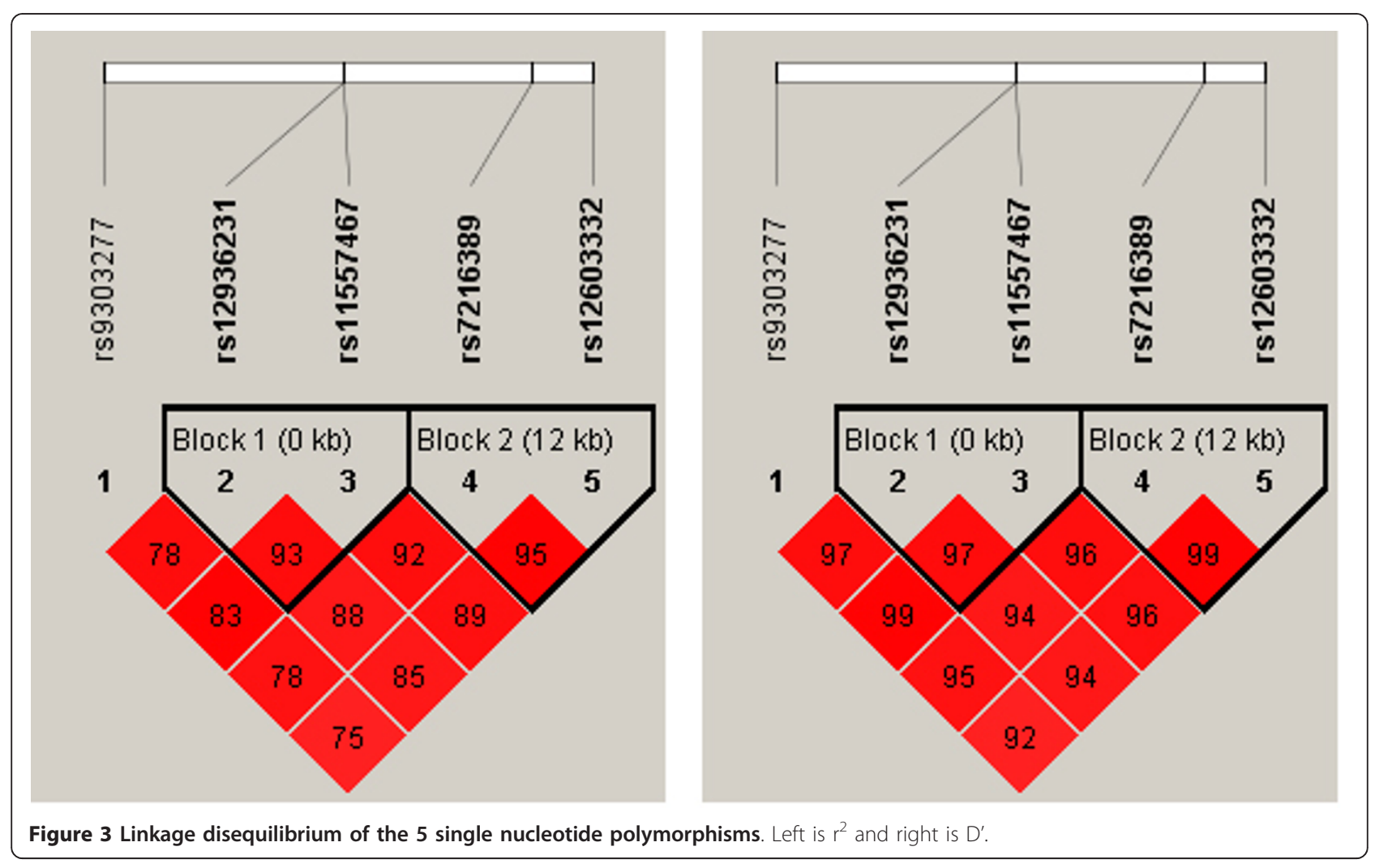


Table 4 Haplotype frequencies of the 5 single nucleotide polymorphisms in cases and controls

\begin{tabular}{lcccc}
\hline Haplotype & Cases, n (\%) & Controls, $\mathbf{n ~ ( \% )}$ & P & OR (95\% Cl) \\
\hline T C C C G & $903(0.681)$ & $735(0.650)$ & Ref & 1.00 \\
T C C T G & $45(0.034)$ & $39(0.035)$ & 0.968 & $1.06(0.69-1.65)$ \\
C T G T T & $324(0.244)$ & $327(0.289)$ & 0.021 & $0.81(0.67-0.97)$ \\
\hline
\end{tabular}

The order of 5 SNPs: rs7216389, rs12603332, rs12936231, rs9303277, rs 11557467 95\% Cl, 95\% confidence interval; OR, odds ratio; Ref, reference haplotype used for comparison.

Cantero-Recasens et al. revealed that ORMDL3 could inhibit the expression of the sarco-endoplasmic reticulum $\mathrm{Ca}^{2+}$ pump and lead to reduced endoplasmic reticulum $\mathrm{Ca}^{2+}$ concentration and increased unfoldedprotein response[23], which suggests that ORMDL3 might be involved in inflammation and asthma.

\section{Conclusions}

In summary, our case-control study revealed the 5 SNPs we studied significantly associated with asthma in an adult Han Chinese popoulation, but no SNP had an independent effect. In agreement with previous studies, variants rs7216389, rs12603332 and rs12936231 had striking effects on ORMDL3 and GSDMB gene expression, with the presence of the risk allele for each SNP robustly increasing the expression of the genes. Further studies are required to elucidate the mechanism of 17q21 variants predisposing asthma susceptibility.

\section{Acknowledgements}

We thank all the participants in the study. This work was supported by grants from the Natural Science Foundation of China $(30771201,81072452)$

\section{Author details}

'Key Laboratory for Experimental Teratology of the Ministry of Education and Department of Medical Genetics, Shandong University School of Medicine, Jinan, Shandong 250012, PR China. ${ }^{2}$ Department of Respiratory Internal Medicine, Qilu Hospital, Jinan, Shandong 250012, PR China.

\section{Authors' contributions}

QL conceived and designed the study. RQ conducted the laboratory experiments, developed protocols, performed the statistical analysis, and drafted the manuscript, $\mathrm{HZ}$ helped with genotyping, and $\mathrm{YG}$ and $\mathrm{QL}$ polished the final manuscript. AW participated in the clinical survey and sample collections. All authors read and approved the final manuscript.

\section{Competing interests}

The authors declare that they have no competing interests.

Received: 4 May 2011 Accepted: 11 October 2011

Published: 11 October 2011

\section{References}

1. Chae SC, Li CS, Kim KM, Yang JY, Zhang Q, Lee YC, Yang YS, Chung HT: Identification of polymorphisms in human interleukin-27 and their association with asthma in a Korean population. J Hum Genet 2007, 52(4):355-361.

2. Cookson W: Genetics and genomics of asthma and allergic diseases. Immunol Rev 2002, 190:195-206.

3. Moffatt MF, Kabesch M, Liang L, Dixon AL, Strachan D, Heath S, Depner M, von Berg A, Bufe A, Rietschel E, et al: Genetic variants regulating ORMDL3 expression contribute to the risk of childhood asthma. Nature 2007, 448(7152):470-473.

4. Hjelmqvist L, Tuson M, Marfany G, Herrero E, Balcells S, Gonzalez-Duarte R: ORMDL proteins are a conserved new family of endoplasmic reticulum membrane proteins. Genome Biol 2002, 3(6):RESEARCH0027.

5. Breslow DK, Collins SR, Bodenmiller B, Aebersold R, Simons K, Shevchenko A, Ejsing CS, Weissman JS: Orm family proteins mediate sphingolipid homeostasis. Nature 463(7284):1048-1053.

6. Carl-McGrath S, Schneider-Stock R, Ebert M, Rocken C: Differential expression and localisation of gasdermin-like (GSDML), a novel member of the cancer-associated GSDMDC protein family, in neoplastic and nonneoplastic gastric, hepatic, and colon tissues. Pathology 2008, 40(1):13-24.

7. Tavendale R, Macgregor DF, Mukhopadhyay S, Palmer CN: A polymorphism controlling ORMDL3 expression is associated with asthma that is poorly controlled by current medications. J Allergy Clin Immunol 2008, 121(4):860-863.

8. Bouzigon E, Corda E, Aschard H, Dizier MH, Boland A, Bousquet J, Chateigner N, Gormand F, Just J, Le Moual N, et al: Effect of 17q21 variants and smoking exposure in early-onset asthma. N Engl J Med 2008, 359(19):1985-1994.

9. Madore AM, Tremblay K, Hudson TJ, Laprise C: Replication of an association between 17q21 SNPs and asthma in a French-Canadian familial collection. Hum Genet 2008, 123(1):93-95.

10. Sleiman PM, Annaiah K, Imielinski M, Bradfield JP, Kim CE, Frackelton EC, Glessner JT, Eckert AW, Otieno FG, Santa E, et al: ORMDL3 variants associated with asthma susceptibility in North Americans of European ancestry. J Allergy Clin Immunol 2008, 122(6):1225-1227.

11. Wu H, Romieu I, Sienra-Monge JJ, Li H, del Rio-Navarro BE, London SJ: Genetic variation in ORM1-like 3 (ORMDL3) and gasdermin-like (GSDML) and childhood asthma. Allergy 2009, 64(4):629-635.

12. Ferreira MA, McRae AF, Medland SE, Nyholt DR, Gordon SD, Wright MJ, Henders AK, Madden PA, Visscher PM, Wray NR, et al: Association between ORMDL3, IL1RL1 and a deletion on chromosome 17q21 with asthma risk in Australia. Eur I Hum Genet.

13. Galanter J, Choudhry S, Eng C, Nazario S, Rodriguez-Santana JR, Casal J, Torres-Palacios A, Salas J, Chapela R, Watson HG, et al: ORMDL3 gene is associated with asthma in three ethnically diverse populations. Am J Respir Crit Care Med 2008, 177(11):1194-1200.

14. Hirota T, Harada M, Sakashita M, Doi S, Miyatake A, Fujita K, Enomoto T, Ebisawa M, Yoshihara S, Noguchi E, et al: Genetic polymorphism regulating ORM1-like 3 (Saccharomyces cerevisiae) expression is associated with childhood atopic asthma in a Japanese population. $J$ Allergy Clin Immunol 2008, 121(3):769-770.

15. Leung TF, Sy HY, Ng MC, Chan IH, Wong GW, Tang NL, Waye MM, Lam CW: Asthma and atopy are associated with chromosome 17q21 markers in Chinese children. Allergy 2009, 64(4):621-628.

16. Wang P, Liu QJ, Li JS, Li HC, Wei CH, Guo CH, Gong YQ: Lack of association between ADAM33 gene and asthma in a Chinese population. Int J Immunogenet 2006, 33(4):303-306.

17. Purcell S, Neale B, Todd-Brown K, Thomas L, Ferreira MA, Bender D, Maller J, Sklar P, de Bakker PI, Daly MJ, et al: PLINK: a tool set for whole-genome association and population-based linkage analyses. Am J Hum Genet 2007, 81(3):559-575.

18. Shi YY, He L: SHEsis, a powerful software platform for analyses of linkage disequilibrium, haplotype construction, and genetic association at polymorphism loci. Cell Res 2005, 15(2):97-98.

19. Laitinen T, Rasanen M, Kaprio J, Koskenvuo M, Laitinen LA: Importance of genetic factors in adolescent asthma: a population-based twin-family study. Am J Respir Crit Care Med 1998, 157:(4 Pt 1):1073-1078.

20. van Beijsterveldt CE, Boomsma DI: Genetics of parentally reported asthma, eczema and rhinitis in 5-yr-old twins. Eur Respir J 2007, 29(3):516-521.

21. Moffatt MF, Gut IG, Demenais F, Strachan DP, Bouzigon E, Heath S, von Mutius E, Farrall M, Lathrop M, Cookson WO: A large-scale, consortiumbased genomewide association study of asthma. $N$ Engl J Med 363(13):1211-1221

22. Verlaan DJ, Berlivet S, Hunninghake GM, Madore AM, Lariviere M, Moussette S, Grundberg E, Kwan T, Ouimet M, Ge B, et al: Allele-specific chromatin remodeling in the ZPBP2/GSDMB/ORMDL3 locus associated with the risk of asthma and autoimmune disease. Am J Hum Genet 2009, 85(3):377-393. 
23. Cantero-Recasens G, Fandos C, Rubio-Moscardo F, Valverde MA, Vicente R: The asthma-associated ORMDL3 gene product regulates endoplasmic reticulum-mediated calcium signaling and cellular stress. Hum Mol Genet 19(1):111-121.

Pre-publication history

The pre-publication history for this paper can be accessed here: http://www.biomedcentral.com/1471-2350/12/133/prepub

doi:10.1186/1471-2350-12-133

Cite this article as: Qiu et al:: Association of genetic variants in chromosome 17q21 and adult-onset asthma in a Chinese Han population. BMC Medical Genetics 2011 12:133.

Submit your next manuscript to BioMed Central and take full advantage of:

- Convenient online submission

- Thorough peer review

- No space constraints or color figure charges

- Immediate publication on acceptance

- Inclusion in PubMed, CAS, Scopus and Google Scholar

- Research which is freely available for redistribution

Submit your manuscript at www.biomedcentral.com/submit
() Biomed Central 